\title{
Om Grundtvigs poetik med særligt henblik på den bibelske inspiration ${ }^{1}$
}

\author{
AfChristian Thodberg
}

Med den bog om Grundtvig, Det handlende ord. N.F.S. Grundtvigs digtning, litteraturkritik og poetik 1798-1819 (G.E.C. Gad 1980), der idag fremlægges til forsvar for doktorgraden, er der ydet en imponerende videnskabelig indsats, og bogen vil i mange år blive stående som håndbogen $\mathrm{i}$ og introduktionen til første del af Grundtvigs forfatterskab, en værdig afløser af F. Rönnings for sin egen tid dygtige arbejde. Forf.s videnskabelige indsats kan kun for alvor måles ud fra et personligt kendskab til Grundtvig-arkivet, hvor dette det største danske forfatterskab ligger gemt. Forf. vedgår med rette s. 12 sin gæld til Steen Johansens uundværlige Bibliografi over N.F.S. Grundtvigs skrifter I-IV og registranten i 30 bind over Grundtvigs papirer. Disse to værker danner den ramme, som forf. har udfyldt i form af "en tekstrettet litteraturhistorisk monografi om Grundtvigs forfatterskab 1798-1819, der med henvisning til Grundtvigforskningen samtidig kan tjene som en håndbog $\mathrm{i}$ den nyere litteratur om Grundtvig“ (s. 12). Enhver, der har siddet med vanskeligt læselige manuskripter eller manuskriptdele med Grundtvigs håndskrift og indholdsmæssigt præget af Grundtvigs krogede tankegang, læser forf.s bog med særlig beundring og især sætningerne på s. 12: "En hovedpointe ligger i fuldstændigheden ...", og s. 13: "Det bliver en pointe ved denne bog, at én læser på tværs af de forskellige emneområder har gennemset samtlige papirer fra de første tyve år af Grundtvigs skribentvirksomhed ". Det er i eminent forstand et pionerarbejde at præstere en gennemgang og tolkning af det trykte og utrykte forfatterskab i sammenhæng. Jeg må så tilføje, at udtryk som "fuldstændigheden" og "samtlige papirer " nok kan få enhver opponent med ære livet til at hvæsse kløerne. Det skal jeg få lejlighed til at vende tilbage til.

1. Opposition ved disputatshandlingen 16. december 1980 (let bearbejdet). 
Under dette arbejde med forfatterskabet ud fra indre kriterier har forf. fortjenstfuldt været i stand til at omdatere og reorganisere dele af det utrykte forfatterskab på overbevisende måde, se fx. s. 608, hvor en fejlplaceret stump af en manglende kommentar til Roskilde-Riim 1812 findes. En sådan opdagelse kan kun gøres af en forsker med en vel oparbejdet hukommelse.

Sin fremgangsmåde karakteriserer forf. summarisk s. 12 som "en nærlæsning af enkelttekster og enkeltværker ud fra litterære kriterier, dernæst en sammenstilling af delresultater til mere omfattende helheder og endelig en indplacering i samtidens litterære miljø". Sin nærlæsningsteknik udvikler forf. s. 16-18 uden efter min mening helt nøje at præcisere, hvad han mener, men det bliver der lejlighed til at vende tilbage til. Hvad angår vurderingskriterier, s. 19-21, anlægger forf. en historisk holdning ved "at bedømme teksterne ud fra den poetik, der har været Grundtvigs og hans tids" (s. 19) og lader forfatterskabet falde i tre dele: en klassicistisk - nyklassicistisk (1798-1804), en overvejende romantisk (1805-10) og endelig Grundtvigs opgør med udefra kommende normer i perioden 1811-19, der benævnes Grundtvigsk-nationalkristelig.

Inden for Grundtvig-forskningen bekender forf. sig til den retning, som han selv betegner som "akademisk" med bl.a. Toldberg og Albeck som fortjenstfulde forgængere og bl.a. Rubow og Diderichsen som metodiske vejvisere, mens forf. tager afstand fra den forskningsretning, der kaldes "den eksistentielle " med bl.a. Jørgen Elbek og Aage Henriksen som hovednavne. Forf. definerer selv sit arbejde "som en akademisk - altså dokumenterende og verificerbar - studie i en del af det overleverede Grundtvigske tekstkorpus" (s. 28) - et ordvalg, som den Gamle nok ikke ville have godtaget.

Forf. gennemgår sin terminologi og det videnskabelige apparat (s. 28-33), og det er ikke mindst herudfra klart, at forf. har fremragende litteraturvidenskabelige og filologiske kundskaber og evner til at realisere sit program. Hans gengivelser af håndskrifter er usvigelig sikker, han kan islandsk og latin (vistnok ikke græsk og hebræisk), ja, jeg vil rent ud sige, at forf. er en af de få med klassisk-akademisk dannelse, der endnu er i stand til at præstere et arbejde som det, der idag er fremlagt.

Forf. siger s. 28, at bogen kan "benyttes som hånd- og op- 
slagsbog ved studiet af enkelte Grundtvig-tekster eller -år", men han siger også , at den kan "læses i én flugt ". Ja, det er vi nogle stykker, der har skullet, men jeg vil indrømme, det er vanskeligt! Det hænger sammen med "fuldstændigheden", der kræver at alt, stort og småt, skal tages med, og i den henseende er forf. kompromisløs og må vel også efter sit eget program være det, men det giver undertiden en ujævn fremstilling, når fx. s. $195 \mathrm{f}$. den ikke særligt vigtige fejde i det langelandske læseselskab omtales, s. 293-94 spørgsmålet om bevarelsen af gravhøje, s. 360-63 gennemgangen af de 12 kobberstik-digte, der tydeligvis er Grundtvigsk venstrehåndsarbejde, eller ekskursen s. 327-28 om dimisprædikenen, der dog så ofte er blevet behandlet, osv., men det er åbenbart "fuldstændighedens " omkostninger.

Just bogens karakter af håndbog rejser spørgsmålet om bogen som disputats. Kort sagt: er der nogen tese? Det fremgår ikke af den principielle indledning. Den er så at sige åben for en tesedannelse.

Tesen optræder først i konklusionen s. 883 ff.: Forfatterambitionerne i det første tiår forbereder $\mathrm{i}$ det andet tiår Grundtvigs utilslørede forståelse af sig selv som symbol på den kommende fornyelse i Norden, og det begrundes i denne sammenhæng, altså til sidst, udførligt psykologisk, åndshistorisk, skønlitterært, politisk, teologisk og religiøst (s. 885-86). Udviklingen skildres historisk s. $888 \mathrm{ff}$, , og det $\mathrm{i}$ en så veloplagt form, at man kunne have ønsket sig hele bogen skrevet $\mathrm{i}$ det sprog - med een og samme "flugt". Sluttelig fremdrages overraskende termen "det handlende ord", der har givet bogen navn, og det skal indrømmes: det er en god titel. Folk vil faktisk tro, forf. er grundtvigianer - og købe bogen. Til gengæld kan man ikke sige, at denne term - det er jo faktisk også en tese - er blevet begrundet $i$ det foregående - et problem, som jeg senere skal vende tilbage til.

Her vil jeg imidlertid holde mig til selvsymbolikken som tese. Hvorfor har forf. ikke indarbejdet den som en drivende kraft $i$ selve afhandlingen og dermed begrundet, i hvilken forstand bogen lægger nye forskningsresultater frem, og endelig dermed gjort bogen spændende læst "i én flugt?" Det kunne - for nu i flæng at nævne nogle steder - være sket s. $146 \mathrm{i}$ omtalen af geniæstetikken, s. 298, hvor Grundtvig gør Optrin 1809 personligt som sit "Livs Haab", s. 314 med Grundtvig i vækkerrollen, 
s. 325-26 i forbindelse med hans jeg i dimisprædikenen, s. 332 i forbindelse med jeg-formen i "Sørgekvad ved Prinds Kristians Død «, s. 336 med Grundtvig som Danmarks røst, osv., osv. for blot at nævne eksempler fra det første tiår. Det er jo en stigende kurve, der nok kunne have fortjent løbende kommentarer.

Hvad teser angår, møder den udholdende læser hele fire, hvis han når så langt som til det engelske resumé. Selvsymbolikken optræder som nr. 4 s. 942 . De øvrige er 1) resultatet af første del: Grundtvigs tilegnelse af en kunstnerisk udtryksmåde 1798-1804, s. 931 nederst, 2) i 1805-10 tilslutter Grundtvig sig den romantiske filosofi men med en undertrykt kristen overbevisning, s. 935, og 3) Grundtvig tilegner sig - det er også s. 935 - et arkaiskdynamisk sprog i de voldsomme national-moralske opgør. Om man nu vil kalde disse tre opsummerende resultater for teser, er straks mere diskutabelt.

Selvsymbolikken er m.a.o. den afgørende og egentlige tese. Men bogens ydre ramme, afgrænsningen 1798-1819, er jo bestemt af et andet hensyn, nemlig Grundtvigs forhold til den samtidige litterære verden, dels afhængigheden af bestemte normer, dels hans endelige frigørelse fra dem med udsendelsen af sidste hæfte af Danne-Virke IV i januar 1819.

Jeg kan ikke se andet, end at forf. kommer i klemme med sin tese og sin afgrænsning. Bogen er blevet stor nok, men det er for mig et spørgsmål, om den ikke burde have været strammet betydeligt og udvidet til at omfatte et større tidsrum. Epilogen s. 861 ff. viser, at forf. udmærket kunne have gjort det, og epilogen afspejler også indirekte forf.s dårlige samvittighed desangående. På s. 866 siges det med rette om "Nyaars-Morgen" 1824, at digtet "er kulminationen af Grundtvigs selvsymbolik " og "den totale frigørelse fra gængse forestillinger om digtning i samtiden ". Burde afhandlingen så ikke have omfattet tidsrummet 1798-1824? Og gør man forholdet til den litterære samtid til udgangspunkt, burde så ikke "Skribenten Nik. Fred. Sev. Grundtvigs Literaire Testamente" 1827 have været respekteret som slutpunkt? Det gør forf. også selv på en måde s. $861 \mathrm{og}$ s. 879, nederst, og med rette, for i 1827 nåede Grundtvig den klarhed, der for alvor fik ham til at gå sine egne veje i forhold til samtiden. 
En anden indvending skal anføres. Forf.s force er bl.a. hans indgående kendskab til litteraturen $i$ Grundtvigs samtid og i det 18. århundrede. Den sætter ham i stand til præcist at påvise Grundtvigs forlæg, både hvad angår form, æstetik og indhold helt ned til symboler og enkeltord. For forfatterskabet 1798-1810 spiller det en stor rolle, og jeg mener bl.a. af den grund, at afhandlingens første bind er det mest helstøbte. Her hører forf.s tidligere store arbejde fra 1965 hjemme, som i parentes bemærket havde en markant tese - her kommer forf.s litteratur-videnskabelige holdning til sin ret, ja fejrer triumfer, når det drejer sig om gennemgangen af "Skoleholderne", "Brevet", dagbøgerne, påvisningen af de norrøne indslag, osv., ligesom Grundtvigs romantiske holdning og dens forhold til kristendommen og fx. begrebet "asarus" $\mathrm{i}$ forhold til Grundtvigs senere bedømmelse bestemmes sikkert og overbevisende i kraft af forf.s viden og indtrængende analytiske metode.

Men jeg mener, at forf. kommer i klemme i 2. bind af afhandlingen. Her vokser stofmængden kolossalt, og forf.s gennemgang bliver af den grund undertiden ret summarisk. Her afvikler Grundtvig sit forhold til litteraturen og de æstetiske normer og bliver i stedse højere grad sig selv, får egne former og ganske særligt sit eget univers af ord og begreber. Fortolkeren må i stigende grad forstå Grundtvig på hans egne præmisser.

Det er klart, at det især må være her, forf. ser faren ved den eksistentielle tolkning, som han i sin indledning undsiger. Men jeg kan på den anden side ikke se, hvordan han undgår at komme hen i nærheden af den. I konklusionen ihvertfald synes jeg, han strejfer den. Kort sagt: jeg synes, at forf. undertiden har svært ved at blive for alvor kongenial med Grundtvig. Forf. bruger stadigvæk sit litteraturvidenskabelige værktøj, men det slår ikke altid til.

Et par mindre eksempler og siden et større: På s. 492 gennemgår forf. "Strandbakken ved Egeløkke" fra "Saga " 1812 og undrer sig over brugen af ordet "Naadig":

Naadig lod Gud sig forbarme

Over mig usle og arme. 
Som en mulighed henfører forf. det til en Ewald-påvirkning se s. 493, midten. Men hvis linierne af Grundtvig virkelig er fra 1811, havde han al mulig grund til at tale om Guds kærlighed og nåde - og hvis det er fra før 1811, skulle en teolog så have nødig at gå over ån efter vand? Inspirationen ligger tydeligt fx. i Davids psalmer, fx. den 51. Kort sagt: Bibelen er det univers, hvori Grundtvig fra nu af bevæger sig frit. Det er i perioden fra 1810 og fremefter også et vidnesbyrd om hans frigørelse, hvad jeg ikke synes, forf. har megen sans for. Det skal jeg straks vende tilbage til.

Det andet eksempel henter jeg fra "Paaske-Lilien". Forinden skal jeg sige, at jeg iøvrigt betragter forf.s gennemgang af dette digt som et af afhandlingens højdepunkter. Det drejer sig om strofe 9 , de kendte linier:
Paaske-Blomst! en Draabe stærk
Drak jeg af dit gule Bæger,
$\mathrm{Og}$, som ved et Underværk
Den mig hæver, vederkvæger;
Svane-Vinge, Svane-Sang
Synes mig af den udsprang;
Vaagnende jeg seer de Døde
I en Paaske-Morgen-Røde.

Det er de to sidste linier, det drejer sig om. Iflg. forf. s. 721 $ø v e r s t$ er det "en digterisk vision af de døde, der i Jerusalem efter Jesu opstandelse forlod gravene og vandrede rundt i byen", og der henvises til Matt. 27,52-53.

Har forf. selv opfundet den skrifthenvisning? Mon han ikke har arvet den fra Hans Brix? Disse hellige mænd opstod iflg. Mattæus langfredag, da jordskælvet efter Jesu død indtraf. Men det er da rigtigt, at de første viste sig efter Jesu opstandelse.

Hovedsagen er efter min mening den eskatologiske opstandelse, opstandelsen engang, som Grundtvig visionært allerede ser $\mathrm{nu}$ - et tema, han just $\mathrm{i}$ denne periode frigjordes til at tage op, bl.a. i sine prædikener.

Kort fortalt synes jeg, at forf. - og andre litteraturfolk - nok forstår dramaet og indholdet $\mathrm{i}$ den almindelige litteratur, men ikke i Bibelen, der reduceres til en slags sproglig konkordans, hvor man søger oplysning om sære billeder og begreber uden at 
give agt på sammenhængen. Men hvis man ikke tør give sig Grundtvigs nye tankeverden i vold - bl.a. det bibelske og gudstjenstlige drama - kan man heller ikke helt ud tolke Grundtvig. Og det kan vel på den anden side næsten ikke gøres, uden at man nærmer sig den eksistentielle tolkning, som forf. ikke bryder sig om.

Som et større eksempel på forf.s litteraturvidenskabelige fremgangsmåde og dens begrænsning vil jeg gerne fremdrage hans gennemgang af "Deilig er den Himmel blaa", s. 355-58. Jeg mener, der er to planer, en dobbelthed i denne salme, som forf. ikke får fat på - en dobbelthed svarende til den i Velkommen igen Guds engle små fra 1824, hvor det nok er børn, der synges om, men hvor det alligevel er de voksne, det drejer sig om, fordi det $\mathrm{i}$ syngende stund er de voksne, der skal blive som børn igen sammen med barnet Jesus. At inddrage 1824-salmen her med "Et Barn er født i Bethlehem " 1820 som gennemgangsled, synes jeg heller ikke er urimeligt. Grundtvigs opfattelse af julen som det at blive barn igen ligger fast hos ham, også i perioden 1810-19.

Derfor må jeg også hos forf. angribe tendensen til at gøre motiverne i "Deilig er den Himmel blaa" til gods, der er hentet andetsteds fra, $\mathrm{fx}$. når børnene i digtet gøres til en ydre ramme "en fiktion ", siger forf. - $\mathrm{i}$ lighed med pigerne i Willemoes-elegien, og når forf. s. 357-58 søger $\mathrm{i}$ litteraturen for at finde belæg for de vinkende stjerner.

Hvad stjernerne angår, kan man i stedet analysere især Grundtvigs samtidige digtning. Det er nødvendigt at gøre på egen hånd, for den ellers trofaste Toldberg giver ingen hjæelp.

Stjernerne hører hjemme i nytårsdigtene. Ved deres skin skues tilbage på det svundne år (Til Vennerne Hersleb og Sibbern, Nyaaret 1809, PS I 102-3). Ved stjernernes glimt stiger oldtiden op "fra de Fæderne Høje" (Drapa om Villemoes 1808, PS I 29) også i "Duggen " 1808 (PS I 83) og digtet "Til Justitsraad Pram " 1808 (PS I 90) og i "Ved min Færd til Middelsyssel " 1808 (PS I 133), her s. 283. Dvs. stjernerne har en ledende funktion. De "vinker" så at sige.

I digtet "Julefesten" 1809 , se s. 307 , er der tale om to slags stjerner: de vilde, tindrende stjerner $\mathrm{i}$ det nordiske hedenskab, der sættes i modsætning til kristendommens: 
Stjærnerne blinke paa lysere Grund Hisset i Sommerens Rige, (PS I 170)

fordi de bebuder julebudskabet.

I "Sværmeriet “ 1811, se s. $504-8$, er der også to slags stjerner, fx. hedningernes:

Men flyver du vidt over Mark og Eng

Og over de Søer saa brede,

Da lettelig vorder til Baare den Seng,

Som Stjernerne dig monne rede;

(str. 14, US II 153).

Og i "Sværmeriet" som et forvarsel om kristendommen i form af himmellængsel hedder det i strofe 26:

I Norden det er kun om Vinterens Tid

Den Himmel sig dyb monne hvælve,

Da vinker hver Stjerne saa blinkende blid,

Da tie de brusende Elve;

Ei blomstre de Enge for Øiet til Lyst,

Men Ahnelser avles saa dybt udi Bryst,

Mod Himlen de hige og stunde.

(US II 155)

hvortil så kan føjes, hvad forf. nævner s. 506, billedet af den falske kristendom, rationalisternes malede stjerne på kirkeloftet $\mathrm{i}$ str. 66-67. - Eksemplerne kan iøvrigt suppleres.

Jeg mener ud fra enkeltanalyser at være kommet til et delresultat - for at blive i forf.s sprog, og jeg kan derfor ikke forstå, at forf. drager litteraturens land og rige rundt for at oplede motivet andre steder.

De to slags stjerner spiller just en vigtig rolle omkring "Deilig er den Himmel blaa". De falske stjerner bliver et billede på dødens nat, og ligbåren redes af dem - det motiv, der gribende kommer til udtryk i de "to fortænkte strofer" - sådan kalder forf. dem med urette s. 357 - der i originalmunuskriptet går forud for barnesalmen. De strofer handler om jorden eller rettere sagt graven som en seng: 
En Himmelseng det var vi fik Og opad stirre maa vort Blik

Ei vorde Søvnens Fange,

Den Himmel er saa deilig blaa

Af gyldne Stjerner rundt derpaa

Indvirkedes saa mange.

(US II 76)

Denne strofe hører med til krisedigtene 1810 og kan vel tolkes sådan, at den personlige dødsangst er på vej til at blive overvundet, for der er to slags stjerner. Netop den personlige optakt sammen med den betydning, stjernemotivet $\mathrm{i}$ forvejen havde hos Grundtvig - gør det rimeligt at forstå "Deilig er den Himmel blaa" som andet og mere end en barnesang. Det har sin solide baggrund i Grundtvigs mest alvorlige overvejelser og har derfor et dybere plan foruden det barnlige.

Optakten "Deilig" foregriber H.C. Andersens eventyrprosa, siger forf. s. 357. Det er nærmest en banalitet $\mathrm{i}$ denne sammenhæng, når man betænker, hvad Grundtvig lægger $\mathrm{i}$ ordet "deilig “. Det bliver for ham - vi skal se det om lidt i prædikenerne fra 1811 - et adjektiv, der knyttes til Bibelens billedord. Hele første strofe bliver da et gennemført bibelsk billede hos Grundtvig.

Den næste strofe:

Kommer Smaa og hører til!

Jeg for eder sjunge vil

Om saa lys og mild en Stjerne,

Jeg det veed, I høre gierne:

Himlen hører eder til.

er nok udadtil fortællerens opfordring til børnene, men ret beset er det en elegant parafrase af hele Markus 10,14 (som forf. også anfører): Lad de små børn komme til mig; dem må I ikke hindre; thi Guds rige hører sådanne til - ord, som Grundtvig kendte ud og ind fra dåbsritualet - dvs. ord, der dybest set ikke er henvendt til børn alene, men også til voksne. Det har også betydning for fortcellerens funktion; det er ikke en gammel bedstefar à la H.C. Andersen; det er en forkynder. Altså: det er ikke blot en barnesang, og børnene er ikke kun en "ramme" eller en "fiktion". 
Man må ikke misforstå mig; i mange enkeltheder kan jeg naturligvis være enig med forf. i tolkningen, men indholdet røber gang på gang dobbeltheden: at det ikke blot er en sang for børn, kun en "idyl".

Forf. kan s. 356 ikke finde belæg for tolkningen af de tre vise mænd som en astrolog, en konge og en kongesøn. Det er igen de bibelske forbilleder - her fra Daniels Bog - der dominerer. Som Messias-profeti og samtidsspejling spillede profeten Daniel den største rolle for Grundtvig, se fx. s. 610-11. Det må ses i forbindelse med hans interesse i 1808-10 for Johannes Åbenbaring; de to skrifter ligner jo hinanden, hvad angår de profetiske syner. I Daniels Bog finder vi stjernetyderne - her finder vi kongen, Nebucadnezar, og hans søn, Beltsazar. For dem begge bebudedes iflg. den klassiske tradition just Messias som tidernes midtpunkt. Det er det, der demonstreres i salmens enkle form, der set fra det synspunkt bliver en mini-udgave af "Sværmeriet" 1811.

Om den gamle astrolog hedder det som bekendt:

Langt herfra i Østerland

Stod en gammel Stjernemand,

Saae fra Taarnet vist paa Himlen,

Saae det Lys i Stjernevrimlen,

Blev i Sind saa barneglad.

I formen er strofen barnlig, men i indholdet reflekterer den jo stjernernes lys som symbol for målet for menneskets higen $i$ historien. Det er "Østen", det er Babel, der er blevet nutidigt. Det er Babel, der nu omvender sig svarende til Grundtvigs håb for sin samtid 1808-10. Det er m.a.o. salmens dybere plan. Og hvorfor kaldes den viise for "barneglad «? Jo, stjernemanden er et billede på den verdsligt kloge, af en Nikodemus, der kom på bedre tanker - den Nikodemus fra Johannes-evangeliets 3. kapitel, der fra og med 1811-prædikenerne baner vej for barnemotivet hos Grundtvig.

Da de tre mænd endelig finder Jesus, hedder det om stjernen:

Thi i Barnets milde Øie

Funklende og klar den sad.

Der står netop ikke: I Jesu milde Øie (s. 356). Det kan sammen-. holdes med, hvad Grundtvig senere i "Kvædlinger" 1815 sagde 
om de tre vise fra østen, "der atter engang vil komme, og neie for den spæde Nyfødte, for den gjenfødte Christendom " (US II 83). Dvs. "Barnet" i den citerede strofe er både Jesus og det kristnede barn - et samlet udtryk for kristendommens kærne som det at blive barn igen sammen med Kristus, en tanke, der sam sagt netop i 1811-12 slår afgørende igennem hos Grundtvig, fx. i "Udby Have" 1811 (s. 501). At det allerede kan findes her, bør ikke undre. I poesi foregriber Grundtvig livet igennem de teologiske erkendelser, der først senere kommer op i mere argumenterende form.

I sidste strofe tolkes stjernen i form af det klare guddomsord

Som han os lod aabenbare

til at lyse for vor Fod

et citat fra ps. 119,105: "Dit ord er en lygte for min fod, og et lys paa min stie". Jeg nævner det her; jeg veed nemlig ikke, om forf. er klar over det. For i forbindelse med "Til Dana" 1815 leder han fortvivlet efter det, når han s. 663, linie 3 f.o. siger, at vendingen "i Skin af Ordets Kierte" er ubibelsk!

"Deilig er den Himmel blaa" er her trukket frem som en kendt tekst for at vise, at forf. med sit litteraturvidenskabelige apparat ikke til enhver tid er lige kongenial med Grundtvig. Det gælder stjernemotivet som digtets baggrund, de bibelske motivers betydning og dermed dobbeltheden i digtet, der altså har en tydelig pointe for voksne.

For to teksters eller tekstgruppers vedkommende vil jeg pege på afgjorte mangler $\mathrm{i}$ afhandlingen. I begge tilfælde angår det perioden 1811-19, altså afhandlingens 2. bind.

VK 1814 behandles s. 617-20 og får i forhold til de to andre verdenskrøniker en stedmoderlig omtale. Herfra henter forf. ellers sin afsluttende tese, termen "det handlende ord ", nemlig s. 897-98 i udredningen om verbets særlige karakter på hebræisk. Det burde forf. så afgjort have gjort mere ud af i forbindelse med den almindelige gennemgang af VK 1814.

Når forf. s. 619-20 skal skildre sproget i VK 1814, læner han sig for meget op ad Toldberg, hvis karakteristik efter min mening ikke er helt rammende.

I sin genfortælling af den bibelske historie står VK $1814 \mathrm{i}$ tydelig gæld til de gængse indledende bibelparafraser i Udby- 
prædikenerne. Begge dele hører til Grundtvigs bedste prosa. Med Toldberg blot at kalde sproget "velafbalanceret hypotakse" og "billedfattigt ", er ikke dækkende (s. 619). Pointen er, at det er bibelsk eller for at tale med VK 1814: uden hedensk "Billedprunk « (VK s. 201).

Interessant for Grundtvigs poetik er hans gennemgang af det hebræiske sprogs ejendommeligheder. Grundtvig siger selv, "at jeg er et Barn i de hellige Sprog, og kan ikkun stave saa smaat udi Faders Bog,..." (VK s. 190). Det fremgår med al ønskelig tydelighed, og hebræisken fremdrages da også her alene for at begrunde Grundtvigs egen poetik, men i den henseende er hans teorier også af største interesse.

Hebræisk står den oprindelige rent poetiske billedskrift nærmest (VK s. 183). Verbum har først og fremmest 3. person singularis og minder derfor om "Hans Gierning, som var og er og bliver " (VK s. 192), altså Guds. Hebræerne kendte ikke præsens, "thi saa maatte det være i Grundsproget der udtrykte Sandhed, da Alt i Tiden maa være forbigangent eller tilkommende, det Nærværende er ingen Stilstand men en Overgang, og det udtrykte Ebræerne saa levende ved at bruge Participiet, ligesom de ved at bruge Præteritum give tilkiende, at Gierningen var gjort for Gud, før den kom tilsyne. Infinitivet er Tidens uadskilte, flyvende Billede, medens Imperativet svæver óver Tiden som en Herrens Engel, og har derfor ingen tredie Person" (VK s. 19293). De "braadne Tempora " mangler: "...Grundsproget var beskikket for Mennesker som gjorde heelt hvad de skulde. Ligesaa aabenbar er Grunden, hvi Ebræerne ei have nogen Conjunctivus eller Optativus, thi Uvished, Tilfældighed og alt hvad der er og foraarsager Uro og Tummel var udenfor det uskyldige Menneske, og kunde ligesaa lidt afpræge sig $\mathrm{i}$ hans Tungemaal, som det herskede i hans Inderste" (ibd.).

Det er som nævnt kun til dels en dækkende beskrivelse af det hebræiske sprogs karakter - men til gengæld af Grundtvigs digteriske stil fx. i hans norrønt inspirerede digte og ganske særligt den kristnede stil i Paaske-Lilien i englenes og Gabriels sange talt netop i "overgangen" mellem fortid og fremtid - det er derfor, det er "det handlende ord" - og i den ydre form alene udtrykt med substantiver og verber, hvorover det himmelske imperativ næsten bogstaveligt talt svæver. Det er en præcis be- 
skrivelse af det handlende ords plads og form, der forøvrigt genfindes i de poetiske passager i prædikenerne, som jeg om lidt kommer til.

Forf. er selv inde på denne stilform s. 406-7. Her nævner han også den ejendommelige stil, hvor ordene føder hinanden, og han siger med rette: "Det er svært at udpege et forbillede" (s. 406). Jeg mener heller ikke, at Grundtvig bliver sig stilen bevidst, før han arbejder med den i den kristnede form. Han omtaler den i VK 1814 (s. 205), stadigvæk i forbindelse med hebræisken, når han taler om "Samfundet mellem Ordene i det poetiske Sprog". Det "maa kundgiøre sig ved en øiensynlig Avling, saa at det ene Ord har udviklet sig af det andet,...». Det sker ved "de Ord som udtrykke nærliggende Forestillinger og ligne hinanden i Lyd". De store forbilleder kunne Grundtvig finde og fandt da også i den bibelske poesi, hos Esajas og i Psalmerne og de hymniske dele af Bibelen overhovedet.

Kort sagt: Det er et prægnant citat fra VK 1814, forf. bringer s. 897-98, men man undrer sig over, at han ikke i højere grad har udnyttet VK 1814 og forøvrigt også sprogafhandlingerne i "Danne-Virke" inklusive det utrykte fragment om ordet, der nævnes s. 706, på deres egne steder $i$ fremstillingen både for at begrunde termen "det handlende ord " og for at udfolde Grundtvigs poetik overhovedet.

Der er eet stort område, som forf. ikke har behandlet med den grundighed, der ellers præger ham. Det er pradikenerne. Og når jeg trækker dem frem, er det ikke blot, fordi jeg selv er teolog. Men Grundtvig prædikede det meste af sit liv, og netop i prædikenerne udvikles Grundtvigs billedsprog og poetik $i$ praksis, således at prædikenerne kan siges at danne overgang til den senere salmedigtning. I indgående analyser af prædikenerne i 20'erne og 30 'erne har jeg andetsteds søgt at påvise denne overgang. Også af den grund har jeg været spændt på forf.s behandling af prædikenerne i 10 'erne.

Naturligvis kender forf. prædikenerne i perioden. Han refererer fx. kort de bevarede prædikener fra tiden på Langeland (s. 151, 192, 196-97 og 223) og ganske særligt prædikenerne i København efter Udby-tiden, fx. fra efteråret 1813 (s. 593, 660-61, 907, etc.), og dertil har jeg ikke egentlige bemærkninger. Men 
det mest omfattende og samlede tekst-korpus, prædikenerne i Udby fra 1. søndag efter trinitatis 1811 til 9. søndag efter trinitatis 1813, op imod 2000 sider og dækkende over 2 års præstegerning, gøres der forbavsende lidt ud af, se s. 477-79 og 585-86. Dog gør forf. med rette opmærksom på prædikenen 2. pinsedag, den 7. juni 1813, på grund af dens brug af naturbilleder.

I den forbindelse henvises til ligheden med den holdte pinseprædiken, den 6. juni 1824.

Hvis forf. havde læst den opmærksomt, kunne han have hentet god inspiration til en analyse af Udby-prædikenerne. Men iøvrigt kunne tilskyndelsen også være kommet fra et vigtigt fragment om prædikenstilen, nemlig fasc. 72.I.4, som forf. behandler på s. 597. Her siger han, at afhandlingen "i kassationen af normer og ydre regler ... svarer ... til Grundtvigs poetik ". Med andre ord: Prædikenen og den egentlige poesi stilles af forf. på linie med hinanden. Men jeg kan ikke se, at forf. gør alvor af denne ligestilling.

I fragmentet slår Grundtvig fast, at han ikke vil lade sig diktere af en norm à la Bastholm. Man făr imidlertid på grundlag af karakteristikken af prædikenerne s. 585-86 ikke noget indtryk af, at Grundtvig sprænger nogle "normer". Man kan godt finde samtidige eller tidligere prædikanter, der til indledning genfortæller evangeliet og dernæst finder et udhævet tema, som udvikles i prædikenens hoveddel. Det mener fx. Rönning (II,2 s. 8).

Iflg. Rönning og forf. kan det se ud, som om prædikenerne $\mathrm{i}$ Udby-tiden er traditionelle - når undtages 2. pinsedag 1813 (s. 586), som jeg om lidt skal vende tilbage til.

Men først vil jeg pege på afhandlingen i fasc. 72 . Her siger Grundtvig om prædikenens sprog: "At selv her Sproget bliver billedligt, som i Jesu og Pauli Taler, er ligefrem, thi saalænge det Himmelske kun sees i Speilet, maa det ses som et Billede og uden Indbildningskraft kunde Mennesket umulig have Forestilling om det Usynlige, ... « (.p. 28-29). Altså Jesu taler og Paulus' taler danner forbilleder. Derefter går Grundtvig over til i almindelighed at tale om velklang, som han først og fremmest finder i verset: "At Verset skal være det mest velklingende, derom tvivler vel Ingen, og Grunden er nem at udfinde, thi hvad er Verset andet end en Form hvor vi sammensmelte Ordene, fremtrylle et Billede af det udelelige Ord hvis Lignelse Ordet oprindelig er!" 
(p. 31). Med "det udelelige Ord “ tænkes på Kristus - svarende til begyndelsen af Johannes-evangeliet: I begyndelsen var ordet, der også tolkes således $i$ et andet fragment, "Om Ordet og Modersmaalet ", fra Dannevirke-tiden (VU III 278). Det afgørende făr Grundtvig sagt i det flg. i fasc. 72: "Frit kan Man sige, at Talen er mere velklingende alt som den nærmer sig Verset, og i den velklingende Prosa er altid et Versemaal forborgent, som Man blandt andet kan tydelig see $\mathrm{i}$ den lutherske Bibel saavelsom $\mathrm{i}$ Cathechismus" (p. 31-32).

Det er i det flg. sætningen "i den velklingende Prosa er altid et Versemaal forborgent ", der skal tages som udgangspunkt for en kort gennemgang af Udby-prædikenerne. Det mener jeg er. nødvendigt som et supplement til forf.s fattige karakteristik s. 58586 og for disputatsens anliggende overhovedet.

Det poetiske bryder kraftigt igennem på 3. søndag efter trinitatis, den 30. juni 1811, med lignelserne om det tabte får og den tabte drakme (Lukas 15,1-10): "O hvilke deilige hvilke trøstefulde Billeder paa Guds Barmhjertighed er ikke disse", siger Grundtvig. De er et spejl, der er blevet "saare klart», således "at vi kun behøve at oplade Øiet for deri at see Guds Herligheds Glands og hans Vaesens rette Billede" - det sidste er et citat fra Hebræerbrevet 1,3, der allerede i 1809 fascinerede Grundtvig (PS I 120), og som fra nu af bliver hovedskriftstedet for brugen af billeder og poesi i prædikenerne - så at sige den bibelske legitimation. Stilbrudet $\mathrm{i}$ den foreliggende prædiken er iøvrigt ganske tydeligt.

Et stemningsopsving nås i prædikenen den 8 . september 1811 , Grundtvigs fødselsdag, der falder på 13. s.e. trin., hvor evangeliets indledningsord lyder: "Salige ere de øine, som see, det I see" (Lukas 10,23 ff.), en tekst, der hver eneste gang sætter Grundtvig i bevægelse. Man behøver ikke at lede efter de poetiske prædikener. Der er - som det skal vises - bestemte fix-punkter.

Den næste store prædiken følger på Allehelgensdag, den 3. november 1811, som forf. med rette omtaler s. 477-78, fordi vi her for første gang møder selvsymbolikken.

Prædikenerne i advent 1811 er vigtige som baggrund for VK 1812. Spejl-motivet dukker med stor kraft op igen på 1. juledag. Her inddrages også naturen, nemlig fuglene, der forudgriber indholdet i en salme som Alt hvad som fuglevinger fik. Vigtigt er det 
at bemærke, at naturbillederne her og i det flg. så at sige kommer ind på bibelsk licens. Bagved ligger Jesu ord i Mattæus-evangeliets 6. kap.: Se til himlens fugle; de sår ikke og hoster ikke og samler ikke $i$ lade, og dog giver jeres himmelske Fader dem foden; er I ikke meget mere vard end de $(6,26)$, se til markens liljer, hvorledes de vokser; de arbejder ikke og spinder ikke $(6,28)$.

I kirkeåret 1811-12 sker der til at begynde med ikke ret meget, men fra og med Mariæ Bebudelsesdag, den 15. marts 1812, sætter en Kingo-rus ind med stor opstemthed. Hovedordene er markelig, sar, forunderlig, gladelig. Højstemtheden kulminerer ejendommeligt nok langfredag, den 27. marts, og flg. stykke af prædikenen kan udskrives som prosadigt:

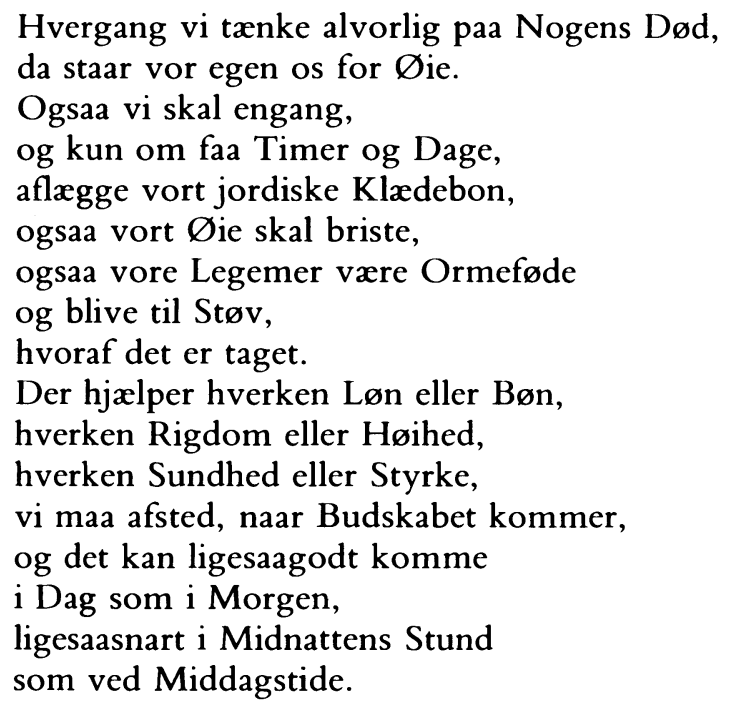

Det er tydeligvis præget af de mange Kingo-vers i sammenhængen og af Kingos tale om forkrænkeligheden i salmer som Far, verden, farvel og Sorrig og glade. Man lægger mærke til, hvordan formen her som i andre prosadigte strammer til i slutningen med alliterationer og andre former for rim.

Forf. er selv opmærksom på denne stilform hos Grundtvig, se fx. s. 115 f. og 579 (fra fasc. 86.2), hvor jeg ganske vist ikke er helt enig med forf. i hans leddeling. På samme måde kunne den s. 633 øverst citerede passage udskrives. Eksemplerne er legio. Grundtvig lyser selv formen i kuld og køn i VK 1814 i to om- 
digtninger af Bibelens prosa. De præsenteres her med teksten fra Chr. VIIs Bibel tv. og "digtene" th.:

Chr. VIIs Bibel:

denne skal trøste os i vor kummer og vore hænders arbejde paa jorden hvilken HERREN haver forbandet. (1. Mosebog 5,29)

forbandet være Canaan, han skal være tieneres tiener for sine brødre ... lovet være HERREN, Sems Gud, og Canaan skal være deres tiener. Gud venligen overtale Japhet, og han skal boe i Sems pauluner, og Canaan skal være deres tiener. (1. Mosebog 9,25-27)
VK 1814:

Denne skal vorde

Vor Trøst i vor Kvide

I Hændernes Møie paa Jord:

Jorden, som Herren forbanded. (s. 28)

Canaan være forbandet, Og sine Brødres Tieneres Tjener! Lovet være Jehovah!

Sems Gud er Han.

Canaan er deres Træl.

Gud oplade for Japhet

Ham til en Bolig

Sems Paulun!

For dem skal Canaan trælle.

(s. 54)

Langfredags-digtet fra før kunne evt. sættes i forbindelse med digtet "Ved liden Regines kiste", som forf. gennemgår s. 520, og som citerer hele 4 Kingo-vers og også har tanken om forkrænkeligheden (PS III 27-28). Også i det flg. kan peges på de overraskende stilformer i prædikenerne til belysning af samtidige begivenheder $\mathrm{i}$ almindelighed og det øvrige forfatterskab i særdeleshed.

Påskedag, den 29. marts, domineres også af Kingo, og indholdet forudgriber Paaske-Lilien 5 år senere.

Opstemtheden dukker op igen på Kristi Himmelfartsdag den 7. maj 1812. Skriftstedet Salige ere de øine møder vi nok engang her, hvor himmelfarten nutidiggøres. Det falder nøje i tråd med Grundtvigs teologiske interesse for de store Kristusbegivenheder, der gøres visionært gældende. Just herom kan uddrages et prosadigt: 


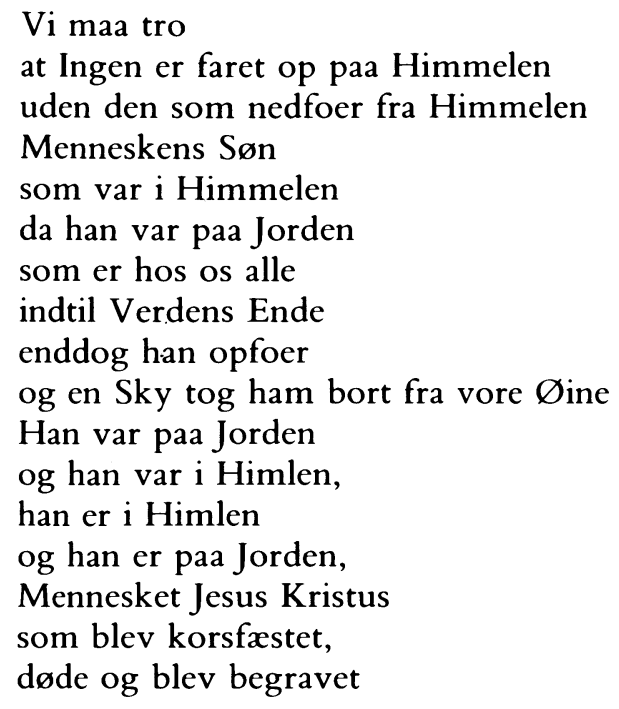

Teologisk er det af stor interesse, at Kristi gerning netop i de poetiske sammenhænge gøres gældende helt uden de lutherskpietistiske betingelser, Grundtvig ellers med forkærlighed stiller. Det betingelsesløse udtrykkes i vendingen:

han er i Himlen

og han er paa Jorden.

Billedet af jorden som en jammerdal afstrejfes med andre ord, og man tænker på linierne fra 1824 :

Mit Land, siger Livet, er Himmel og Jord, Hvor Kiærlighed boer!

(GSV III 148).

Opstemtheden fortsætter den flg. søndag, den 10. maj, hvor også selvsymbolikken kommer ind: menigheden ville høre, hvis Gud opvakte en ny Luther, " og maaske hører han af sin inderlige Barmhjærtighed sine troendes Bønner, saa det sker endnu i vore Dage" (BPr 51).

Begejstringen slutter 1. pinsedag, den 17. maj 1812, hvor pinseberetningen fra Apostlenes Gerninger følges af en kommentar, der kan udskrives som et prosadigt, hvoraf følger det første led: 


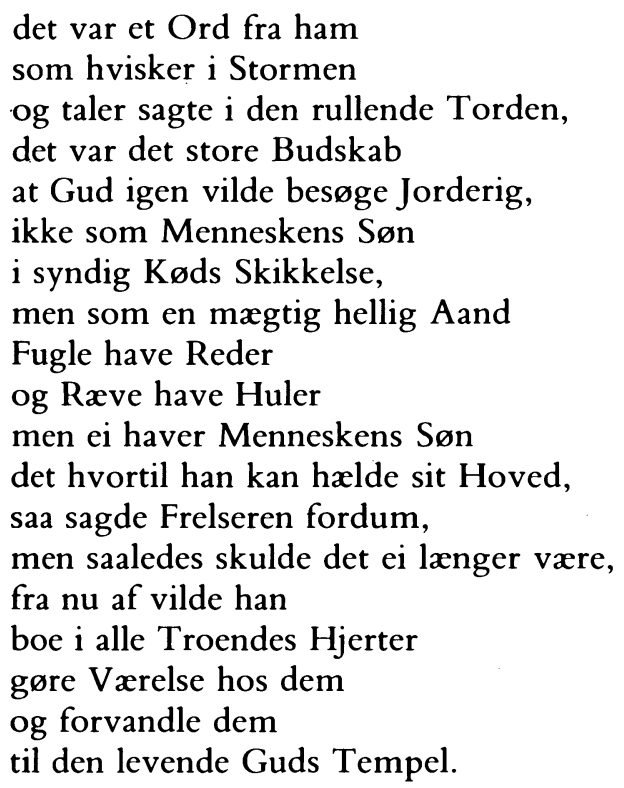

Det typiske er, at opstemtheden holder sig i nogle uger. Sådan er det også i Grundtvigs senere perioder som prædikant.

Herefter følger en lang serie straffeprædikener. En ny opstemthed slår igennem $\mathrm{i}$ august-september 1812. Naturbilleder dukker atter op for at begrunde lovsangens naturlighed. Det er igen billederne fra Alt hvad som fuglevinger fik, der forudgribes (12. og 15. søndag efter trinitatis.). Højdepunktet danner som i 1811 13. søndag efter trinitatis, den 23 . august 1812 , hvor ordene Salige ere de oine giver anledning til et prægnant prosadigt om Kristus-historien:

Gud gav ham Vidnesbyrd

da Himlen oplodes ved hans Daab

da Aanden nedfoer

og blev hvilende paa ham,

da Røsten kom fra det Høie

Det er min Søn den Elskelige

$i$ hvem jeg haver min Velbehagelighed

da de samme Ord udsagdes

over Forklarelsens Bjerg

og da der lagdes til 


\begin{abstract}
Ham skal I høre
Faderen vidnede med sin Enbaarne, der han gav ham Magt til at gøre de Døve Hørende og Maalløse talende, ja endog de Hensovne levende igen, ja Faderen beseglede al Sønnens Tale der han opreiste ham fra de Døde og satte ham hos sin høire Haand til vor Fyrste og Frelser, i hvis Navn alle Knæ skulle bøie sig i Himlen paa Jorden og under Jorden.
\end{abstract}

O hvor saligt mon det ikke være at se denne Jesum Guds Herligheds Glands og hans Vaesens rette Billede ... (min understr.).

Det er karakteristisk, at "digtet" efterfølges af en kommentar i almindelig prædikenstil om, hvor saligt det er at se "Jesum Guds Herligheds Glands og hans Væsens rette Billede", altså Hebr. 1,3 , som jeg til indledning pegede på som prosadigtenes bibelske nøgle. Dvs. Grundtvig opfatter selv den forudgående sammenhæng som et "billede", et stykke poesi eller en "velklingende Prosa " med "et forborgent Versemaal ". Her som andre steder er poesien tydeligvis hentet fra Bibelen, idet næsten hele prosadigtet er en bibelmosaik, sidst hymnen fra Filipperbrevets 2. kapitel, som Grundtvig resten af sit liv med forkærlighed vendte tilbage til, og som vi også i det flg. skal se som fast inventar i prosadigtene.

Her kan opstemtheden måske forklares ud fra færdiggørelsen af VK 1812, hvis fortale er dateret til den 2. august 1812 (se s. 547). Der er måske den samme psykologiske baggrund for allehelgensprædikenen den 1 . november 1812. Den nævnes af forf. i forbindelse med skriftet "Hvorfor kaldes vi Lutheraner?", og han siger (s. 565), at den dær trykte prædiken er fra 1 . november. Det er kun delvist sandt, for den trykte prædiken er en særdeles kraftig bearbejdelse af den holdte prædiken, hvilket man kan studere $\mathrm{i}$ andenudgaven af Bibelske Pradikener, hvor begge versioner findes. Den i Udby holdte prædiken (BPr $62 \mathrm{ff}$.) har typisk nok de poetiske indslag. De er her som andre steder neddæmpede eller fjernede i de bearbejdede, trykte udgaver. Forhol- 
det er det samme imellem Søndags-Bogen I-III og de holdte prædikener i Vor Frelsers Kirke. Dvs. at prosadigtene så afgjort hører sammen med den mundtlige fremførelse - en ikke uvæsentlig pointe i Grundtvigs sammenhæng.

Luther-inspirationen i flugt med skriftet "Hvorfor kaldes vi Lutheraner " og udgivelsen af VK 1812 i december spiller sikkert også en rolle for den rent ud fantastiske prædiken på 1. søndag i advent, den 29 . november 1812 , der er een stor udlægning af Johannes Åbenbaring, kap. 3 vers 14-22, dvs. Laodikæa-brevet, især vers 20: "See, jeg haver staaet for døren, og banket; dersom nogen hører min røst, og oplader døren, til ham vil jeg gaae ind og holde nadvere med ham, og han med mig".

I størstedelen af prædikenen er det jeg, dvs. Jesus, der taler. Den er næsten som helhed et prosadigt. For første gang dominerer denne stil totalt. Her skal gengives den indledende linie i almindelig prædikenstil og derefter prosadigtet:

1. sondag $i$ advent 1812

Han kommer til os i ringe Skikkelse, men han siger dog:

luk mig ind, gør mig Ære, thi jeg er din Frelser og din Konge!

Luk mig ind at jeg og min Fader maa have Værelse hos dig, indtil dit Timeglas er udrundet, da skal du faa Lov at følge hjem med os og bo hos mig

i Faderens Hus evindelig

men er det da Ret, at I vil lade Fjenden bo $\mathrm{i}$ det Hus, som jeg har bygt, ja, som jeg har købt igen, ikke for Sølv eller Guld men med mit hellige og dyrebare Blod.

Er det den Tak jeg skal have, 
fordi jeg som var i Guds Skikkelse,

fornedrede mig selv

og tog en Tjeners Skikkelse paa

og blev lydig til Døden

ja til Korsets Død.

Hele prædikenen minder om den romerske kirkes improperier $\mathrm{i}$ langfredagsliturgien, hvor Kristus bebrejdende rækker hænderne ud mod sit folk. En sådan gennemført jeg-prædiken i prosadigtstil er ganske enestående og et ualmindeligt stærkt vidnesbyrd om Grundtvigs selvfølelse. Det er dog ham, der 50-100 gange siger jeg på prædikestolen!

På s. 892, nederst, siger forf.: "Mest prægnant slår selvsymbolikken formentlig igennem i Grundtvigs prædikener" og henviser til 1850'erne. Jeg bider mærke i ordet formentlig. Mon ikke det dækker for forfs. dårlige samvittighed med henblik på prædikenmaterialet overhovedet? Kort fortalt: For forf.s tese om selvsymbolikken og poetikken kunne denne 12-13 siders poetiske jegprædiken 1. søndag i advent 1812 have været et markant punkt $\mathrm{i}$ bevisførelsen - på linie med Paaske-Lilien. Og hvis "det handlende ord" poetisk skal findes nogen steder, så må det være her.

For at gå videre med prædikenerne: Jeg-stilen er lige så gennemført 2. søndag i advent, den 6 . december, og på 3. søndag i advent, den 13. december. I den sidst nævnte siger han såmænd: Her er jeg igen, jeg fulgte jer i kirkeåret - hvorefter frelseshistorien oprulles. 3 søndage i træk bryder Grundtvig alle tænkelige regler og normer for prædikenens form. Han havde allerede realiseret den sprængning af normerne, som han omtalte $\mathrm{i}$ sin afhandling om prædikengenren i 1813 , i fasc. 72 , som jeg startede med.

Dette voldsomme udbrud af selvfølelse kan også forklare væsentlige samtidige begivenheder. Forf. omtaler s. 545-46 de vigtige breve til Mynster af den 1. december og til Molbech den 2. december 1812, og jeg spørger: Mon det ikke er prædikenernes opstemte Jeg-Grundtvig, der er afgørende for tidspunktet for afsendelsen af disse skæbnesvangre breve?

Prædikenen på 1 . juledag 1812 omtaler forf. s. 385 i forbindelse med hyrdelivet som ideal - vigtig for digtene i 1811 og 1817. Prædikenen slutter med et lille prosadigt: 
(om hyrderne)

De havde seet med deres Øine at der var Sti $[g]$ e

mellem Himmel og Jord

hvor Englene fare imellem, de havde seet Herren af Himlen som et Menneske[s] Søn

og vidste da

at Han vilde tage $[\mathrm{dem}]$ som Brødre

med sig til Himlen.

(hermed slutter prædikenen)

Her forudgribes indholdet i Velkommen igen Guds engle små fra 1824.

Kirkeåret 1812-13 er i begyndelsen uden poetiske indslag. En undtagelse danner 2. pinsedag, den 7. juni 1813, som forf. fortjenstfuldt gør opmærksom på s. 586, men det er som tidligere nævnt ikke første gang, naturbilleder forekommer. Dertil må for den pågældende prædikens vedkommende bemærkes, at den for 8 siders vedkommende er eet storladent prosadigt, hvoraf indledningen - omfattende det af forf. citerede stykke - præsenteres her:

Solen den skinner saa blidt i det Høie, Blomsten og Kornet opvoxer af Jorden til Føde og Lyst, Skoven er grøn og Fuglene synge, love den himmelske Fader som giver dem Føden enddog de ei selv saae eller høste.

Ja I Elskelige, vist er den skinnende Soel de frugtbare Marker og blommede Enge i den Troendes Øine liflige Billeder af det Verdens Lys, 
Guds Herligheds Glands

som Faderen sendte til Verden,

af Ordets hellige Vext

og Opblomstring i Troendes Hjerter.

[NB: min understregning]

hvor man lægger mærke til de af mig understregede ord, Guds Herligheds Glands, fra Hebr. 1,3, det bibelske belæg for den poetiske billedbrug. Her er det vigtigt at slå fast, at naturbillederne bliver et billede på indholdet af Johs. 3,16, det lille evangelium: Således elskede Gud verden, at han hengav sin Son, den enbårne, for at hver den, som tror pa ham, ikke skal fortabes, men have det evige liv. Hermed forudgribes de vældige prædikener i 1823-24 op imod De Levendes Land. Man kan fornemme betydningen af Johs. 3,16 og forvarslet om De Levendes Land i prosadigtet i prædikenens slutning:

(Johs. 3,16)

det gladeste Budskab

som hørtes paa Jorden, det eneste Budskab

som haver Magt

til at give os Freden

med Gud og os selv,

til at give os Lys udi Mørket,

Trøst udi Nøden

Ro i de bittre, de ængstelige Timer

naar vi skal sige Verden det sidste Farvel,

Salighed hisset,

hvor Dagen ei skifter

og Aaret ei endes,

i Evigheds Land.

6. søndag efter trin. den 25 . juli 1813 kommer i prædikenerne det sidste prosadigt i perioden. Formen er nu blevet fast:

O Naade uden Lige,

Trøst uden Ende,

Gud er retfærdig 
og giør den retfærdig
som er af Jesu Tro.
Saa veed vi da Vei til Himlen,
Ingen kan fare derop
uden Han som farer ned
Menneskens Søn
som er i Himmelen
men i Ham skal den Troende opfare,
Ingen var retfærdig paa Jorden
uden Han som blev lydig til Døden
ja Døden paa Korset,
men i Ham skal den Troende retfærdiggiøres.

Just prosadigt-stilens fasthed i juli 1813 kunne måske kaste lys over det allerede omtalte udmærkede eksempel, forf. bringer på s. 579 øverst. Det er netop fra 7. juli. Og på fortalen til "Krønikens Gienmæle", der udkom den 8 . juli 1813 , se s. 580 , hvor den - "en fantasifuld digterisk prosa " - omtales.

Prosadigtformen genfindes efter Udby-tiden, fx. 1. juledag 1813 og 2. pinsedag 1814, der er en tydelig efterklang af 2. pinsedag året før, og $\mathrm{i}$ den patetiske afskedsprædiken 2. juledag 1815 (se s. 660). Derefter bliver den et fast element i Præstøprædikenerne og overhovedet i 20 'erne, hvor stilen kulminerer i 1823-24.

Den tungtvejende indvending mod denne afhandling bliver forf.s ejendommelige distance til den bibelske poesi og kristne begrebsverden. Det hører nu engang med til almindelig akademisk dannelse; det er ikke en specialitet for teologer! Og ihvertfald turde det være indlysende, at man ikke kan nærme sig Grundtvig med denne anti-teologiske holdning uden fatale konsekvenser. Det er her blevet eksemplificeret i forbindelse med gennemgangen af Dejlig er den himmel blå og til sidst i forbindelse med prædikenerne. Her når forf. ikke tilnærmelsesvist op på det niveau, hvorpå han behandler andre tekster, og en virkelig nærlæsning af dem kunne som anført have bidraget væsentligt til belysning af to af forf.s vigtigste anliggender: Grundtvigs poetik og selvsymbolikken. Man tør slet ikke tænke på, hvordan forf. vil behandle Grundtvigs salmer fra hans senere periode. 
Den "fuldstændighed ", som forf. så kraftigt slår på (se her s. 20), lever han altså efter min mening ikke op til; han mangler simpelthen et vigtigt perspektiv i Grundtvigs forfatterskab. Helt konkret: Hvorfor forbigås i håndskriftsregistret (s. 989) fasc. 10, der dog hører med til perioden? Denne fascikel rummer bl.a. prædikenerne til 5. og 13. søndag efter trinitatis 1818, der just er instruktive eksempler på den euforiske prædikenstil, der her er gjort til en hovedsag.

Til slut et par ord om bogens udstyr; den fremtræder meget smukt; trykket er også pænt, men papiret skinner irriterende.

Når bogen skal være en håndbog, burde den have været udstyret med flere registre: et kronologisk og fuldstændigt værkregister, et virkeligt udbygget sagregister, og foruden det personregister, der nu er opstillet sammen med det nødtørftige sagregister, burde der også have været et almindeligt personregister, hvad angår Grundtvig-forskningen.

Håndskriftsregistret s. 989-91 burde have været trykt i smalle spalter; som det nu står, får man ondt $\mathrm{i}$ øjnene.

Hvordan kan en dannet akademiker på s. 980, 2. spalte, finde på at opføre Paulus' breve i alfabetisk orden begyndende med Efeserbrevet - i stedet for den klassiske orden: Romerbrevet, 1. og 2. Korinterbrev osv.? Overhovedet ville et særligt skriftstedregister have været en fordel og hjælp, fordi det fx. ville vise, hvordan Grundtvig prioriterer bestemte skriftord.

Den sproglige form er smuk og behersket. Enkelte stilbrud kan dog konstateres: s. 72 med Henriette, der er vaks, s. 73 med Smiths æateskab, der knaser; s. 517 tales om kapellanatet, selv om forf. godt veed, det hedder kapellani; s. 228 kaldes $29 / 2$ for skuddagen, men det er som bekendt 24/2.

Af trykfejl bemærkes, at der s. 49 i den parentetiske kommentar til digtet skal stå str. 12 istedet for 11 . På s. 989,1 . linje, skal der $\mathrm{i}$ opregningen af fascikler stå fasc. 4: 477-78 istedet for 447-78.

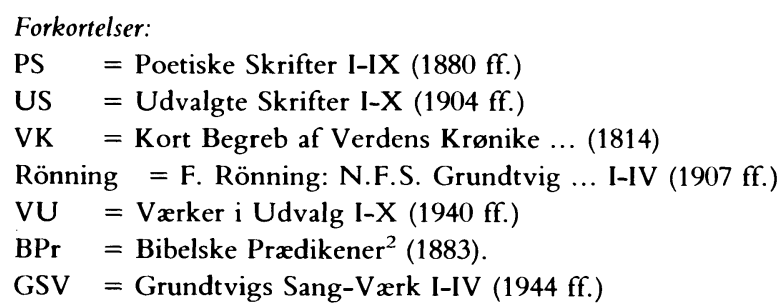

